\title{
Л.В. Пилецкая
}

\section{ПРОДУКЦИЯ ОЛЬГИНСКОГО СТЕКЛОДЕЛАТЕЛЬНОГО ЗАВОДА В ТОМСКОМ ОБЛАСТНОМ КРАЕВЕДЧЕСКОМ МУЗЕЕ ИМ. М.Б. ШАТИЛОВА (ТОКМ): ПРОБЛЕМА АТРИБУЦИИ}

\begin{abstract}
Статья посвящена изучению истории стеклоделия в Томском крае на основе археологических находок продукции Ольгинского стеклоделательного завода, хранящихся в Томском областном краеведческом музее им. М.Б. Шатилова. Подробно рассмотрены технология стекольного дела, основные и вспомогательные производства, состав сырья и материалы, ассортимент выпускаемой продукции. Представлень исторические факты истории стеклоделия в Томском крае, в частности Ольгинского стеклоделательного завода. Статья снабжена фотографиями, характеризуюшими специфику стеклоделательного производства и стекла. Подробно рассмотрен типологический, географический и хронологический состав археологического стекла.

Ключевые слова: археологическое стекло, типичные изделия, музейные собрания, бытовое стекло, стекольные заводы, традиции стеклоделия, виды формования, гутное стеклоделие, выдувание.
\end{abstract}

Объекты археологического наследия занимают особое место в системе историко-культурного наследия и подчас являются единственным свидетельством истории прошлого нашей страны. Они существуют в культурном, музейном и научном пространстве и участвуют в процессе социализации как источник исторической памяти, важный элемент окружающей действительности [1. С. 4]. Вещественные источники, в отличие от письменных, не содержат прямого рассказа об исторических событиях, и основанные на них исторические выводы являются результатом научной реконструкции [2. C. 71].

Археологические объекты позволяют восполнить лакуны в музейных фондах, включаясь в состав музейных коллекций, они становятся музейными предметами с заключенной в них информацией [3. С. 41-42, 60, 78]. Информационный потенциал музейного предмета складывается из трех основных компонентов: атрибутивных характеристик предмета (размер, вес, цвет, материал и т.п.), информации, зафиксированной предметом как ее носителем (тексты, клейма, изображения, знаки и др.), и информации о его происхождении и нахождении в среде бытования, о событиях и лицах, с которыми он был связан [Там же. С. 52]. Важную роль в информативном поле предмета играют его семантические и культурные значения [4. С. 127-129].

В 2015 г. археологическая база данных по г. Томску пополнилась коллекцией разнообразных изделий обиходного характера, представляющих ценность для характеристики повседневной жизни горожан в динамике от XVII-XVIII до XX в. включительно. Предметы были найдены в малоизученном районе г. Томска - Заозёрье [5. С. 76]. В «Отчете об археологических полевых работах в г. Томске в зоне строительства гостиницы по ул. Войкова, д. 36, в 2015 г.» среди находок представлены 34 стеклянных фрагмента, в том 
числе винные бутыли (днища, горлы), с клеймами «З.И.Т.Г» и ЖО.З.Т.Г.И. 1868 г.», выполненные в технике свободного дутья [6. С. 21-28]. Наличие множественных внутренних пузырьков, ручная формовка венчика горла предполагают изготовление не позднее XVIII в. В отчёте высказано предположение, что предметы «выпущены одним из старейших производителей стекла в Томской губернии - Ольгинским стеклоделательным заводом» [Там же. С. 22].

Для подтверждения или опровержения данного предположения следует привести веские доказательства. Во-первых, подтвердить принадлежность предметов с клеймом именно Ольгинскому стеклоделательному заводу и дать ему характеристику. Во-вторых, доказать, что найденные предметы из стекла соответствуют технологии выработки изделий на Ольгинском стеклоделательном заводе.

Представим доказательную базу по первому предположению и подробно рассмотрим археологические предметы из стекла.

Вышеуказанные предметы пополнили фонды ТОКМ в 2018 г. [7]. Коллекция включает 19 археологических предметов из стекла (ТОКМ. № 14368/42, 43, 63, 70, 71, 73, 79-84, 87-93) [8]. Наибольший интерес представляют 9 фрагментов питейной посуды, имеющих клейма на внешней стороне дна (ТОКМ. № 14368/42, 73, 80, 84, 89-93).

Приведем общие и частные характеристики 9 предметов на основе музейной атрибуции. Все предметы изготовлены выдуванием из прозрачного зеленого или прозрачного стекла. В стеклянной массе много пузырьков от воздуха.

Четыре предмета, согласно музейной атрибуции, изготовлены во второй половине XIX в. Первый предмет: дно с фрагментом придонной стенки стеклянной бутылки округлой формы, вогнутое, $\varnothing \approx 9 \mathrm{~cm}, \mathrm{~h}-6,1 \mathrm{~cm}$ (ТОКМ. № 14368/42), на внешней стороне дна клеймо «О.З.Т.Г.И.». Второй представляет фрагмент донца стеклянной бутылки с частью клейма «О.3.Т.[Г.И.]» 4,8 × 3,8 × 0,6-1 см (ТОКМ. № 14368/73). Третий предмет бутылка стеклянная, $\varnothing$ венчика $-3 \mathrm{~cm}, \varnothing$ отверстия $-1,6 \mathrm{~cm}, \mathrm{~h}-24,3 \mathrm{~cm}$, $\varnothing$ дна - 9 см (ТОКМ. № 14368/80). Бутылка с вытянутым горлышком, увенчана налепной лентой с нижней закраиной. Тулово цилиндрической формы. Состоит из 4 проклеивающихся фрагментов. Плечики покатые, дно вогнутое, коническое. На дне клеймо производителя «3.И..Т.Г.» Четвертый предмет нижняя часть стеклянной бутылки (ТОКМ. № 14368/93). Изготовлен выдуванием в форму $\varnothing-8,7 \mathrm{~cm}, \mathrm{~h}-8,7$ см. Донце округлой формы вогнуто с пунтом, по кругу которого - клеймо производителя «З.И.Т.Г.».

Пять предметов датируются 1868 г. Первый - фрагмент донца стеклянной бутылки с клеймом (ТОКМ. № 14368/84), $\varnothing$ основания - 6 см. С внешней стороны имеется клеймо производителя и дата: «[О.]3.Т.[Г.И.] [1]868 г.». Склеен из 2 фрагментов. Второй - основание стеклянной бутылки (ТОКМ. № 14368/89), $\varnothing$ донца - 8,7 см, $\varnothing$ пунта -4 см, h $-11,3$ см. Тулово цилиндрической формы. Состоит из 4 проклеивающихся фрагментов. Основание бутылки со значительным углублением - пунтом, с клеймом производителя с внешней стороны «О.З.Т.Г.И. 1868 г.» Третьим является донце стеклянной бутылки (ТОКМ. № 14368/90). Изготовлено выдуванием в форму $\varnothing-9$ см, $\varnothing$ пунта $-3,9$ см, h -4 см. Донце округлой 
формы, вогнуто ступенчато, с пунтом. На первом углублении по кругу клеймо производителя «О.З.Т.Г.И. 1868 г.». Четвертый - нижняя часть стеклянной бутылки (ТОКМ. № 14368/91). Выдувание в форму $\varnothing-$ 8,4 см, h - 13,5 см. Донце округлой формы, вогнуто ступенчато, с пунтом. На первом углублении по кругу клеймо производителя «О.З.Т.Г.И. 1868 г.». Тулово цилиндрической формы. Последний предмет: нижняя часть стеклянной бутылки (ТОКМ. № 14368/92). Выдувание в форму $\varnothing-$ 8,4 см, h - 10 см. Тулово цилиндрической формы. Донце округлой формы, вогнуто ступенчато, с пунтом. На первом углублении по кругу - клеймо производителя «О.З.Т.Г.И. 1868 г.».

Как сказано выше, предметы имеют клейма разной степени сохранности. Первые четыре предмета имеют клеймо «О.3.Т.Г.И.». Пять предметов «О.З.Т.Г.И. 1868 г.». Для обоснованной расшифровки буквенных обозначений в клеймах приведем архивные данные о стекольных предприятиях, действующих на территории Томской губернии в 1860-1880 гг.

Во второй половине XIX в. существовавшие ранее в Сибири стекольные заводы прекращают производство, но открываются новые предприятия отрасли. Указанная тенденция характерна и для Томской губернии. Так, в архивных документах за 1860-1880 гг. не встречаются сведения о заводе Поклевских-Козелло, ранее действовавшем в Томском округе, но появляется информация о новых стеклоделательных производствах. Известно, что в 1882 г. Н.И. Минский, нарымский купец 2-й гильдии, «устроил стеклоделательный завод невдалеке от Томска» [9. С. 139, 172]. В начале 1880-х завод купил Е.И. Королев [10. С. 153]. Других сведений, раскрывающих место расположения и характер производства, в источнике не указано. Эпизодические сведения относятся к стеклозаводу в Нелюбинской волости, стеклопроизводству предпринимателя К.П. Платонова в Алтайском округе, заводу Б.И. Курлянды по Иркутскому тракту и стеклозаводу вблизи д. Лучановой Томской губернии [11. С. 530].

Несколько подробнее информация об Ольгинском заводе в Богородской волости. Известно, что в 1860 г. им владел томский купец 1-й гильдии Е.П. Исаев и завод располагался под г. Томском в устье р. Томи [12. С. 113]. В документе не указано селение, возле которого располагался завод. Названия производств или фабрик в мировой практике зачастую давались по названию страны или населенного пункта, где располагалось предприятие (Богемское стекло, Севрский фарфор, Гжельская керамика, Хохломская посуда и т.д.). В сведениях о главнейших месторождениях кварцевых песков в Томском округе указано Ольгинское месторождение как очень крупное, расположенное близ п. Ольгинского в 60 км к северу от г. Томска и в 20 км к востоку от р. Томи. Мощность пласта достигала 5 км. Месторождение белого мелкого песка располагается на очень большой территории по p. Шишкобойке. В примечании указано его удаленное положение от железнодорожных и водных путей сообщения [13. С. 44]. Согласно указанным координатам, на карте Томской области расположено с. Ольго-Сапеженка, существовавшее до 1970 г.

История его такова. Основали село переселенцы. Первоначально оно называлось Силантьевкой по имени первого жителя - старообрядца, переселенца из Белоруссии. Причиной переименования села в Ольговку послужило 
утверждение в нем Ольгова дня в качестве престольного праздника. Поскольку, по свидетельству старожилов села, деревня Ольговка уже существовала на территории Туганского района, вошедшего в состав Томского района Томской области, то Силантьевку-Ольговку назвали Ольго-Сапеженкой [14. С. 22-23]. Село стояло в стороне от основной северной дороги в Томск Нарымского тракта, но дорога из Красного Яра в Томск проходила через Ольго-Сапеженку, Успенку, Петропавловку, Виленку. Наличие транспортного пути указывает на возможность доставки стеклянных изделий на рынки г. Томска. Кроме того, село располагалось в местности, богатой лесом, являвшимся сырьем и топливом при изготовлении стекла. Таким образом, есть все основания утверждать, что указанный Ольгинский стеклозавод находился в окрестностях с. Ольго-Сапеженка.

Известно, что в 1860 г. Ольгинский стеклоделательный завод был оснащен паровой машиной. Стеклоделательный завод был необходим Е.П. Исаеву, так как он владел и винокуренными заводами, требовавшими тары, в частности, в Каинском округе Покровской волости [15-17].

Согласно сведениям И. Завалишина, в Томской губернии в 1861 г. «наличествовало 1503 фабрики и завода, из них 2 казенных стекольных завода и 1 частный» [18. С. 36-37]. Данные, приведенные в работе, не дают представления о характере производства, его особенностях, количестве работников, печей, выпускаемой продукции. Указана лишь сумма выручки одного частного предприятия от реализации стеклянной посуды 30740 руб. серебром [Там же. С. 273]. Можно предположить, что речь идет об Ольгинском стеклоделательном заводе, поскольку других сведений о частных заводах в Томской губернии в исследуемых источниках не приведено.

Вместе с тем известен факт приобретения женой Е.П. Исаева в 1861 г. завода в Томске у А. Поклевского-Козелло [12. С. 113]. Вид производства не указан, и можно только предположить, что в Томской губернии в 1861 г. существовало два частных стеклозавода, а не один, как указывает И. Завалишин. В 1864 г. в «Ведомости о фабриках и заводах, находящихся в ведении Томского округа», упоминается «стеклоделательный завод, состоящий в Нелюбинской волости» и принадлежащий томскому купцу 1-й гильдии Егору Исаеву [19. Л. 171]. Данный факт позволяет предположить, что завод, расположенный в Нелюбинской волости, был приобретен у братьев Поклевских-Козелло женой Е.П. Исаева.

На заводе «выделываются» разные изделия из хрусталя: «стаканы, графины, кружки и прочая посуда, оконное стекло, белое, гужирное и зеленое, которое продается по разным ценам». На заводе работало 95 человек, из них 22 мастера, 2 иностранца и 20 русских, 13 шлифовщиков и 60 рабочих. Фабрика «действовала огнем», т.е. на ней имелась одна или несколько стеклоплавильных печей, точное количество печей в документе не указано. Кроме того, имелось 15 шлифовальных станков, работавших на конном приводе, для шлифовки хрусталя. Отсутствие сведений об указанном заводе в более позднее время позволяет предположить о его закрытии после 1864 г. и соответственно расширении производства на Ольгинском заводе. Сведения об Ольгинском стеклоделательном заводе в 1860-1874 гг. приведены в табл. 1. 
Таблица 1. Ольгинский стеклоделательный завод в 1860-1874 гг.

Table 1. Olginsky glass-making plant in 1860-1874

\begin{tabular}{|c|c|c|c|c|c|}
\hline Год & $\begin{array}{c}\text { Число } \\
\text { рабочих }\end{array}$ & $\begin{array}{l}\text { Объем про- } \\
\text { изводства, } \\
\text { тыс. руб. }\end{array}$ & $\begin{array}{l}\text { Кол-во } \\
\text { изделий, } \\
\text { шт. }\end{array}$ & Ассортимент & Оборудование \\
\hline 1860 & & & & & $\begin{array}{c}\text { ? печей, } \\
1 \text { паровая машина }\end{array}$ \\
\hline 1861 & & 30740 & & & \\
\hline 1866 & 169 & 2289,01 & 22637 & Питейная, аптекарская посуда & 2 печи \\
\hline 1868 & 169 & 3847,94 & 39469 & $\begin{array}{c}\text { Питейная, аптекарская посуда, зеленые } \\
\text { кружки, банки }\end{array}$ & 1 печь \\
\hline 1869 & 232 & 42240 & 269500 & $\begin{array}{c}\text { Питейная, аптечная посуда, кружки из } \\
\text { полубелого стекла, банки из полубелого } \\
\text { стекла, шлифованные хрустальные } \\
\text { изделия, оконное стекло }\end{array}$ & $\begin{array}{c}2 \text { печи, } \\
1 \text { паровая машина } \\
\text { в } 15 \text { л. сил }\end{array}$ \\
\hline 1870 & 240 & 52191 & 232900 & $\begin{array}{c}\text { Хрустальные шлифованные изделия, } \\
\text { питейная посуда из белого и полубелого } \\
\text { стекла, кружки из полубелого стекла, } \\
\text { банки и бутылки из полубелого стекла, } \\
\text { стекло оконное полубелое и «бемское» } \\
\text { разных сортов }\end{array}$ & $\begin{array}{c}2 \text { печи, } \\
1 \text { паровая машина } \\
\text { в } 6 \text { л. сил }\end{array}$ \\
\hline 1871 & 217 & 51500 & 354000 & $\begin{array}{c}\text { Питейная, аптечная посуда, кружки из } \\
\text { полубелого стекла, банки из полубелого } \\
\text { стекла, хрустальные изделия шлифо- } \\
\text { вальной работы, стекло оконное полу- } \\
\text { белое и стекло по разным ценам } \\
\end{array}$ & $\begin{array}{c}3 \text { печи, } \\
1 \text { паровая машина } \\
\text { в } 15 \text { л. сил }\end{array}$ \\
\hline 1872 & 215 & 49226 & 282700 & $\begin{array}{c}\text { Питейная посуда, бутылки, штофы и } \\
\text { полуштофы, аптечная посуда, кружки и } \\
\text { банки разных размеров из полубелого } \\
\text { стекла, хрустальные изделия шлифо- } \\
\text { ванной работы, полубелое и «бемское» } \\
\text { оконное стекло } \\
\end{array}$ & $\begin{array}{c}2 \text { печи, } \\
1 \text { паровая машина } \\
\text { в } 15 \text { л. сил }\end{array}$ \\
\hline 1874 & & 67756,53 & 504505 & $\begin{array}{c}\text { Посуда, аптекарские и хрустальные } \\
\text { изделия }\end{array}$ & \\
\hline
\end{tabular}

Применительно к 1866 г. об Ольгинском стеклянном заводе, расположенном в Богородской волости, в устье р. Томи, указано в «Деле о фабриках и заводах, бывших в действии в течение 1866 года» [20. Л. 53-54 (об.)]. В документе значится, что на заводе работало 169 человек, из них 39 мастеров, 52 подмастерья и 78 чернорабочих. Для изготовления изделий «действовала 1 печь». Ассортимент изделий состоял из двух видов и был невелик: питейная посуда - 18145 шт., что составило 80,2\% от общего объема, и аптечная 4492 шт. (19,8\%). Всего выпущено продукции в количестве 22637 шт. Таким образом, в 1866 г. производство на Ольгинском заводе специализировалось на выпуске массовой продукции.

Сведения за 1868-1869 гг. об Ольгинском стеклоделательном заводе приведены в «Ведомости о фабриках и заводах в Томской губернии в ведении Томского округа Богородской волости от 15 февраля 1868 г.» [21. Л. 9394] и «Ведомости о фабриках и заводах, состоящих в ведении Томского округа Богородской волости 22 октября 1869 года» [22. Л. 114-115]. Завод попрежнему принадлежал томскому купцу 1-й гильдии Егору Исаеву и помещался в деревянном здании. Ассортимент включал 4 вида изделий. Вся продукция на фабрике вырабатывалась на одной печи без применения машин. В наибольшем количестве на заводе «выделывались» питейная посуда и «кружка зелёная». Объем производства питейной посуды составлял 
18945 шт. (48\%), а второй - 12532 шт. (31,7 \%). На фабрике изготавливались еще аптечная посуда и банки (20,3\%). На заводе трудилось 169 русских вольнонаемных работников, в том числе 39 мастеров, 52 подмастерья и 78 чернорабочих. Указаны материалы, используемые для производства стеклянных изделий: песок, глина, известь. Часть сырья доставлялась на завод с р. Томи, другая приобреталась в г. Томске и за его пределами. Сбыт изделий производился в Томске, Барнауле и Красноярске.

В ведомости за 1869 г. указано, что завод становился крупным производством: всего на нем работало 232 человека, в том числе мастеров 77 человек, подмастерьев 35 и чернорабочих 120 человек. Все они - русские, вольнонаемные. Из шести видов ассортимента на заводе больше всего выпускалось оконного стекла - 160000 шт. (59,4\%). Питейной посуды выпустили 50000 шт. (18,6\%), аптечной - 30000 шт. (11,1\%). Из полубелого стекла изготавливались кружки и банки «разных мер». Из хрусталя изготавливали изделия шлифовальной работы. На заводе работало две печи и одна паровая машина в 15 лошадиных сил при шлифовальной фабрике [23. С. 124]. Для производства изделий использовались песок, известь, гужирь, или горькая соль, а также кварц, сода, селитра, поташ. Сбыт изделий производился «по уездным городам и прочим местностям Томской губернии», а также в Томске, Барнауле, Красноярске, Иркутске, Ташкенте. Исходя из вышеизложенного следует, что в 1869 г. происходит наращивание производства за счет увеличения числа рабочих, технической оснащенности завода и расширения географии продаж. Расширяется ассортимент массовой продукции - изготовление оконного стекла, происходит выпуск высококачественной продукции хрустальных изделий шлифовальной работы.

Сведения об Ольгинском стекольном заводе 1870-1872 гг. регулярно указываются в «Ведомости о фабриках и заводах в Томской губернии» [24. Л. 52 (об.), 53], «Ведомости о частных фабриках и заводах, расположенных в Томском округе» [25. Л. 36] и «Ведомости о состоянии Ольгинского стеклоделательного завода томского купца 1-й гильдии Е.П. Исаева за 1872 год» [17. Л. 30-31, 270].

В 1870 и 1871 гг. завод по-прежнему был устроен в деревянном здании, мастера и рабочие размещались в деревянных домах, находящихся при заводе. Ассортимент из 7 видов изделий был разнообразным. На заводе «выделывались» хрустальные изделия шлифованной работы, питейная посуда белого и полубелого стекла, а именно: кружки, банки и бутылки, оконное стекло, стекло «бемское» разных сортов. Общий объем производства в 1870 г. составил 232900 шт., в 1871 г. было выпущено 354000 изделий. Предприятие представляло собой уже крупное производство. Всего на заводе в 1870 г. работало 240 человек, из них мастеров - 78 человек, подмастерьев - 32 человека, чернорабочих - 130 человек. Производство механизировалось: работали уже 2 печи. Кроме того, для шлифовки хрусталя на заводе применялась одна паровая машина мощностью в 6 лошадиных сил.

В 1871 г. на фабрике работало 217 человек, в их числе 70 мастеров, 31 подмастерье, 116 чернорабочих. Среди персонала появляются иностранцы братья Александр, Иосиф, Георгий и Иван Томпсоны. Они родились в Меклембург-Шверине в Германии, разделяли лютеранское вероисповедание и с 1840 г. проживали в России. Указанные сведения подал управляющий завода 
в «именном списке иностранцев, проживающих в Томском округе в Богородской волости» [25. Л. 36]. Данная информация подтверждает изготовление на фабрике изделий из богемского стекла, так как при этом использовались знания и мастерство высококвалифицированных иностранных мастеров. При производстве изделий работало уже три печи. Увеличилась мощность паровой машины при шлифовальной фабрике - 15 лошадиных сил. В «особых сведениях» указаны используемые материалы: песок, известь, гуджирь, или горькая соль, кварц, сода, селитра, поташ. Эти материалы закупались. В 1870-1871 гг. сбыт изготовленной продукции производился по уездным городам и прочим местностям Томской губернии, в том числе и в Томске, Барнауле, а также в Красноярске, Иркутске, Ташкенте. Исходя из вышеизложенного следует, что в 1871 г. на заводе была проведена механизация, сократилось общее число работающих и появились иностранные работники. Разнообразный ассортимент продукции включал дорогие шлифованные изделия из хрусталя и высококачественные стеклянные изделия.

В 1872 г. завод располагался уже в новом, специально построенном деревянном помещении, мастера и рабочие жили в деревянных зданиях, построенных по приказу Е.П. Исаева. В 1872 г. он устроил на свои средства начальную школу для детей рабочих и служащих принадлежавшего ему стекольного завода. Ассортимент состоял из семи видов выпускаемых изделий. Общее количество изделий, выпущенных на заводе, равнялось 282700 шт. Больше всего выпускалось оконного стекла, полубелого и «бемского». Также было изготовлено «питейной посуды, бутылок, штофов, полуштофов и прочих» изделий - 92000 шт. (32,5\%); аптечной посуды - 41100 шт. (14,5\%); кружек и банок разных размеров из полубелого стекла - 10000 шт. (3,5\%) и банок - 1700 шт. (0,6\%). Помимо массовой продукции, на фабрике изготавливали хрустальные изделия шлифованной работы - 11000 шт. (3,9\%). Всего работников на заводе насчитывалось 215 человек, в том числе 65 мастеров, 30 подмастерьев, 120 чернорабочих. Вместе с тем сократилось число печей, их осталось две. При шлифовальной фабрике действовала паровая машина прежней мощности. При изготовлении стеклянных изделий использовались те же материалы, что и ранее, и сбыт продукции производился на той же территории. Таким образом, в 1872 г. заводчик построил новое здание для завода и уделял внимание социальным проблемам рабочих. Вместе с тем на производстве уменьшилось количество печей, произошло сокращение объемов производства при неизменном разнообразии ассортимента. Очевидно, рынок или другие экономические ситуации в крае корректировали объем производства.

Очень краткие сведения об Ольгинском стеклозаводе относятся к 1874 г. В «Общей ведомости о частных фабриках, заводах и заведениях в Томской губернии, бывших в действии в 1874 г.» [26. Л. 316, 320 (об.), 321] указано, что завод выпускал посуду, аптекарские и хрустальные изделия в количестве 504505 шт. [12. С. 113]. Других сведений о заводе в источнике не указано, а приведенные свидетельствуют об увеличении в 22 раза объема выпускаемой продукции.

Динамика Ольгинского стеклоделательного завода объяснима общей социально-экономической ситуацией в регионе. Дореформенный 1860-й г. приходится на период «золотой лихорадки», стимулировавшей развитие промышленности. К числу приоритетных направлений для капиталовложений, 
особенно у купцов-старообрядцев, относилось и стеклоделие [10. С. 189]. Кроме того, развитие в Сибири винокуренного дела во второй половине XIX в. также стимулировало развитие стеклоделия в качестве сопутствующего производства. Последовавшая модернизация производства, качественное улучшение ассортимента выпускаемой продукции, проводимые Е.П. Исаевым, привели сначала к некоторому спаду производства на Ольгинском заводе, но дали свои результаты к середине 1870-х гг.

В 1885 г. разорился хозяин Ольгинского стекольного завода - Е.П. Исаев, и завод купил томский купец 2-й гильдии Е.И. Королев [Там же. С. 287]. Согласно другим сведениям, в конце XIX в. он сам основал близ устья р. Томи стеклоделательный завод [12. С. 79, 113].

Подведем итог исследованию. В 1860-1880-е гг. в Томской губернии существовало шесть стеклопроизводств: Ольгинский стеклозавод, завод в Нелюбинской волости, стеклопроизводство К.П.Платонова в Алтайском округе, завод Н.И. Минского возле Томска, завод Б.И. Курлянды по Иркутскому тракту и стеклозавод вблизи дер. Лучановой Томской губернии. Очевидно, самым крупным производством являлся Ольгинский стеклоделательный завод, что и обусловило гораздо большую информацию о нем в источниках. Завод принадлежал купцу Е. Исаеву, располагался в Томской губернии, в Богородской волости, возле дер. Ольго-Сапеженка, во второй половине XIX в. выпускал питейную продукцию, которая реализовывалась в Томске, Барнауле и Красноярске. Следовательно, расшифровка клейм «О.З.Т.Г.И.», «О.З.Т.[Г.И.]», «З.И.Т.Г.», «З.И.Т.Г.», «[О.]3.Т.[Г.И.] [1]868 г., «О.З.Т.Г.И. 1868 г.», встречающихся на 9 музейных предметах (ТОКМ. № 14368/42, 73, 80, 84, 89-93), может быть связана именно с Ольгинским стеклоделательным заводом: «Ольгинский Завод Томской Губернии Исаева».

Представим доказательства по второму положению: найденные предметы из стекла соответствуют технологии выработки изделий на Ольгинском стеклоделательном заводе.

Для установления состава музейных предметов 14 июня 2018 г. был проведен анализ с использованием растрового электронного микроскопа (JEOL JSM 6000) с энергодисперсионной приставкой в лаборатории кафедры технологии силикатов и наноматериалов Научно-образовательного центра (НОЦ) им. Н.М. Кижнера Томского политехнического университета ${ }^{1}$. В результате анализа трех музейных предметов с клеймами (ТОКМ. № 14368/80, 84, 89) было установлено, что в стекле представленных изделий много воздушных пузырьков (рис. 1-3). В атрибуции музейных предметов также указано наличие воздушных пузырьков в стекле, что подтверждается снимками электронной микроскопии.

Среди материалов, используемых для производства изделий на Ольгинском стеклоделательном заводе, в архивных источниках указаны песок, известь, «гужирь», или горькая соль, а также кварц, сода, селитра, «поташь». Для поташного (калийно-известкового стекла) [27. С. 174-177] характерны следующие оксиды, образующиеся при варке стекла из шихты: $\mathrm{SiO}_{2}$ (оксид кремния), $\mathrm{Na}_{2} \mathrm{O}$ (оксид натрия), $\mathrm{CaO}$ (оксид кальция), $\mathrm{Al}_{2} \mathrm{O}_{3}$ (оксид алюминия, или глинозем), $\mathrm{K}_{2} \mathrm{O}$ (окись калия) [28]. Как видно из данных, приведенных в

\footnotetext{
${ }^{1}$ Автор статьи выражает искреннюю признательность доктору технических наук Ольге Викторовне Казьминой за оказанную помощь в написании статьи.
} 
табл. 2, все перечисленные оксиды, согласно проведенному анализу, присутствуют в исследуемых образцах музейного стекла.

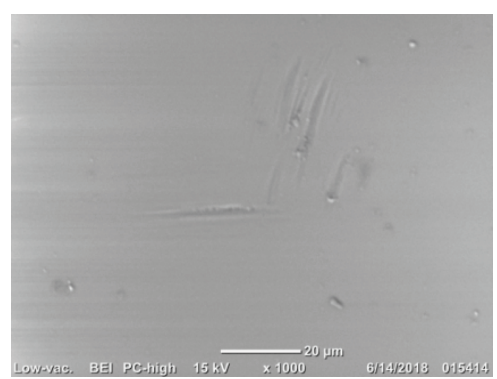

Рис. 1. Структура стекла под электронным микроскопом (ТОКМ. № 14368/80)

Fig. 1. The structure of glass under an electron microscope (TRMLL. No. 14368/80)

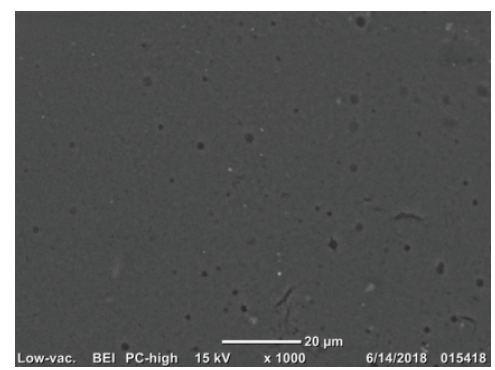

Рис. 2. Структура стекла под электронным микроскопом (ТОКМ. № 14368/84)

Fig. 2. The structure of glass under an electron microscope (TRMLL. No. 14368/84)

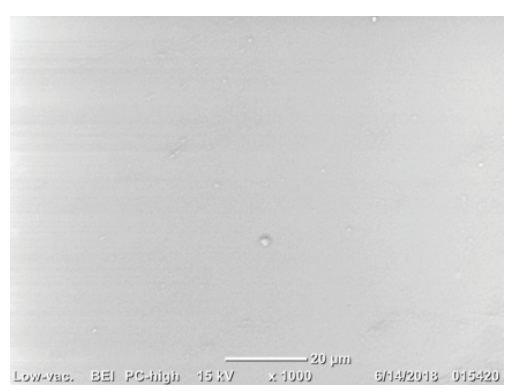

Рис. 3. Структура стекла под электронным микроскопом (ТОКМ. № 14368/89)

Fig. 3. The structure of glass under an electron microscope (TRMLL. No. 14368/89)

Таблица 2. Результаты энергодисперсионного анализа стекол Table 2. The results of energy dispersive analysis of glasses

\begin{tabular}{|c|c|c|c|c|c|c|}
\hline \multirow[b]{2}{*}{$\begin{array}{c}\text { № } \\
\text { п/п }\end{array}$} & \multirow[b]{2}{*}{ Образец } & \multicolumn{5}{|c|}{ Содержание оксидов, масса в \% } \\
\hline & & $\begin{array}{c}\mathrm{SiO}_{2} \\
\text { (оксид } \\
\text { кремния) }\end{array}$ & $\begin{array}{c}\mathrm{Na}_{2} \mathrm{O} \\
\text { (оксид } \\
\text { натрия) }\end{array}$ & $\begin{array}{c}\mathrm{CaO} \\
\text { (оксид } \\
\text { кальция) }\end{array}$ & $\begin{array}{c}\mathrm{Al}_{2} \mathrm{O}_{3} \\
\text { (оксид алю- } \\
\text { миния) }\end{array}$ & $\begin{array}{l}\mathrm{K}_{2} \mathrm{O} \\
\text { (окись } \\
\text { калия) }\end{array}$ \\
\hline 1 & Бутылка стеклянная (ТОКМ. № 14368/80) & 52,29 & 10,6 & 6,44 & \begin{tabular}{|l|}
3,90 \\
\end{tabular} & 0,90 \\
\hline 2 & $\begin{array}{c}\text { Фрагмент донца стеклянной бутылки } \\
\text { с клеймом (ТОКМ. № 14368/84) }\end{array}$ & 30,71 & 6,96 & 3,94 & 1,69 & 1,25 \\
\hline 3 & $\begin{array}{c}\text { Основание стеклянной бутылки (ТОКМ. } \\
\text { № 14368/89) }\end{array}$ & 60,76 & 8,90 & 9,70 & 3,93 & 4,43 \\
\hline
\end{tabular}

Следовательно, лабораторные данные о рецептуре и качестве анализируемого стекла в целом аналогичны данным о составе стекла Ольгинского стек- 
лоделательного завода во второй половине XIX в., зафиксированным в архивных источниках.

Итак, неоспоримый факт существования Ольгинского стеклоделательного завода в Томской губернии подтверждают архивные документы и археологические находки. Музейные предметы из стекла соответствуют технологии выработки изделий Ольгинского стеклоделательного завода, располагавшегося в 1860-1880 гг. на территории Томской губернии. Фонды ТОКМ пополнились подлинными музейными предметами продукции Ольгинского стеклоделательного завода.

\section{Литература}

1. Веденин Ю.А. Основы географического подхода к изучению и сохранению наследия // Наследие и современность. Информационный сборник. Вып. 12. М. : Институт наследия, 2004. C. $3-21$.

2. Базарова Э.Л. К вопросу о культурных ценностях и культурном наследии // Вопросы охраны и использования памятников истории и культуры. М., 1994. С. 68-80.

3. Пищулин Ю.П. Музейные термины / Ю.П. Лищулин, П.Я. Букшпан, М.Б. Гнедовский и др. // Терминологические проблемы музееведения : сб. тр. М., 1986. 137 с.

4. Рындина О.M. «Философия вещей» как универсалия традиционного мировоззрения // Традиционное сознание: проблемы реконструкции. Томск, 2004. С. 127-139.

5. Чёрная М.П., Торощина Н.В., Чернова И.В., Торощин А.Г. Опыт изучения историкоархеологического контекста городского быта в современной застройке Томска // Вестник Томского государственного университета. История. 2016. № 5 (43). С. 76-79.

6. Архив ТОКМ Ф 1. Оп. 4. Д. Б/н.

7. ТОКМ. Коллекционная опись № 1037.

8. ТОКМ № 14368/1-136.

9. Дмитриенко Н.M. Томские купцы : биографический словарь (вторая половина XVIII начало XX в.). Томск, 2014. 336 с.

10. Бойко В.П. Купечество Западной Сибири в конце XVIII - XIX в.: Очерки социальной, отраслевой, бытовой и ментальной истории / под ред. В.П. Зиновьева. Томск, 2007. 424 с.

11. Разгон B.Н. Сибирское купечество в XVIII - первой половине XIX в. Региональный аспект предпринимательства традиционного типа. Барнаул, 1998. 660 с.

12. Краткая энциклопедия по истории купечества и коммерции Сибири : в 4 т. Новосибирск, 1995. Т. 2. Ж-К. $184 \mathrm{c}$.

13. Экономический обзор Томского округа. Издание Томского окружного исполкома. Томск, 1927. $254 \mathrm{c}$.

14. Томилов Н.А. Русские Нижнего Притомья (конец XIX - первая четверть ХХ в.). Омск, 2001. $198 \mathrm{c}$.

15. Ведомости о фабриках и заводах в Томской губернии за 1870 г. // ГАТО. Ф. 3. Оп. 18. Д. 461. Л. 52-53.

16. Ведомости о частных фабриках и заводах, расположенных в Томском округе, за 1871 г. // ГАТО. Ф. 3. Оп. 18. Д. 497. Л. 29.

17. Ведомости о состоянии Ольгинского стеклоделательного завода томского купца 1-й гильдии Е.П. Исаева за 1872 год // ГАТО. Ф. 3. Оп. 18. Д. 532. Л. 97.

18. Завалишин Ипполит. Описание Западной Сибири. Томская губерния. М., 1865. Т. 2. $276 \mathrm{c}$.

19. Ведомости о фабриках и заводах, находящихся в ведении Томского округа, за 1864 г. // ГАТО. Ф. 3. Оп. 18. Д. 347.

20. Дело о фабриках и заводах, бывших в действии в течение 1866 года // ГАТО. Ф. 3. Оп. 18. Д. 353.

21. Ведомости о фабриках и заводах в Томской губернии в ведении Томского округа Богородской волости от 15 февраля 1868 г. // ГАТО. Ф. 3. Оп. 18. Д. 380.

22. Ведомости о фабриках и заводах, состоящих в ведении Томского округа Богородской волости. 22 октября 1869 года // ГАТО. Ф. 3. Оп. 18. Д. 442.

23. Пилеикая Л.В. Информативный потенциал коллекций стекла в государственных музеях Томской области : дис. ... канд. ист. наук. Томск, 2015. 282 с.

24. Ведомости о фабриках и заводах в Томской губернии за 1870 г. // ГАТО. Ф. 3. Оп. 18. Д. 461. 
25. Ведомости о частных фабриках и заводах, расположенных в Томском округе, за 1871 г. // ГАТО. Ф. 3. Оп. 18. Д. 497.

26. Общие ведомости о частных фабриках, заводах и заведениях в Томской губернии, бывших в действии в 1874 г. // ГАТО. Ф. 3. Оп. 18. Д. 586.

27. Безбородов М.А. Технические методы изучения древних стекол / МИА : сб. М., 1965. № 129: Археология и естественные науки. С. 174-177.

28. Kukhta M., Kazmina O., Sokolov A., Arventyeva N., etc. The influence of glass and metal properties on the peculiarities of an item of art's shaping in ethnostyle // IOP Conf. Series : Materials Science and Engineering № 66 (2014). DOI:10.1088/1757-899X/66/1/012046

Lydmila V. Piletskaya, National Research Tomsk State University (Tomsk, Russian Federation). E-mail: plv04@mail.ru

Vestnik Tomskogo gosudarstvennogo universiteta. Kul'turologiya i iskusstvovedeniye - Tomsk State University Journal of Cultural Studies and Art History, 2019, 35, p. 242-254.

DOI: $10.17223 / 22220836 / 35 / 22$

GLASSWARE OF OLGINSKY GLASS FACTORY IN THE TOMSK REGIONAL MUSEUM N.A. M. B. SHATILOV: THE PROBLEM OF ATTRIBUTION

Keywords: archaeological glass; typical products; museum meetings; household glass; traditions of glassblowing; glass factory; productivity; products; types of formation; glassblowing; gutny glassblowing; blowing.

Archaeological objects, replenishing museum collections, become museum objects with the information contained in them.

glass objects were found with stamps "Z.I.T.G" and "O.ZT.G.I.1868" and a variety of internal bubbles in Tomsk, 2015. It is assumed that the items "were released by the oldest glass producer in the Tomsk province - Olginsky glass factory".

It is necessary to confirm the belonging of items with the stamp to Olginsky glass factory and to prove that these glass items correspond to the technology of product development at this plant.

9 fragments of glass were replenished with Tomsk Regional Museum' funds: 4 with the stamp "O.T.T.GI", 5 “O.Z.T.G.I.1868." in 2018. To decipher the stamps, we give archival data on glass factories, Tomsk province in the years 1860-80.

In the Tomsk province there were 6 glass production: Olginsky glass factory, a plant in the Nelyubinsk volost, glass production K.P. Platonov in the Altai district, plant N.I. Minsk near Tomsk, plant B.I. Kurlandy along the Irkutsk road and a glass factory near the village of Luchanovo, Tomsk province. The largest production was Olginsky glass factory. The glass factory belonged to the merchant E. Isaev, located in the Tomsk province, in the Bogorodskaya volost, near the village. OlgoSapezhenko, produced drinking products. Consequently, the deciphering of the stamps on 9 museum objects is connected precisely with the Olginsky glass factory: "Olginsky glass factory of Tomsk Province by Isaev".

The analysis was performed using a scanning electron microscope with an energy dispersive attachment in the laboratory of the Department of Silicate Technology and Nanomaterials of the Scientific and Educational Center n.a. N.M. Kizhner of Tomsk Polytechnic University to establish the composition of museum objects in 2018. Electron microscopy images confirmed the presence of air bubbles in the glass indicated in the attribution of museum objects.

According the archival sources, for the production of glassware at the Olginsky glass factory was used sand, lime, "guzhir", quartz, soda, nitrate, and "potash". Laboratory data on the formulation and quality of the glass analyzed in general are similar to the data on the glass composition of the Olginsky glass factory, recorded in archival sources.

The indisputable fact of the existence of the Olginsky glass factory in the Tomsk province is confirmed by archival documents and archaeological finds. Museum objects made of glass correspond to the technology of making products of the Olginsky glass factory, which was located in 1860-1880 in the territory of Tomsk province. Tomsk Regional Museum' funds: were replenished with genuine museum pieces from the production of the Olginsky glass factory.

\section{References}

1. Vedenin, Yu.A. (2004) Osnovy geograficheskogo podkhoda k izucheniyu i sokhraneniyu naslediya [Fundamentals of a geographical approach to the study and preservation of heritage]. Nasledie i sovremennost'. Informatsionnyy sbornik. 12. pp. 3-21. 
2. Bazarova, E.L. (1994) K voprosu o kul'turnykh tsennostyakh i kul'turnom nasledii [Oncultural values and cultural heritage]. In: Voprosy okhrany i ispol'zovaniya pamyatnikov istorii i kul'tury [Issues of the protection and use of historical and cultural monuments]. Moscow: [s.n.]. pp. 68-80.

3. Pishchulin, Yu.P., Bukshpan, P.Ya., Gnedovsky, M.B. et al. (1986) Muzeynye terminy. Terminologicheskie problemy muzeevedeniya [Museum Terms. Terminological Problems of Museology]. Moscow: [s.n.].

4. Ryndina, O.M. (2004) Traditsionnoe soznanie: problemy rekonstruktsii [Traditional Consciousness: Problems of Reconstruction]. Tomsk: NTL. pp. 127-139.

5. Chernaya, M.P., Toroshchina, N.V., Chernova, I.V. \& Toroshchin, A.G. (2016) Experimental study of the historical and archaeological context of urban lifestyle in the modern urban development of Tomsk. Vestnik Tomskogo gosudarstvennogo universiteta. Istoriya - Tomsk State University Journal of History. 5(43). pp. 76-79. (In Russian). DOI: 10.17223/19988613/43/16

6. The Archive of the Tomsk Museum of Local Lore. Fund 1. List 4.

7. The Archive of the Tomsk Museum of Local Lore. Collection List № 1037.

8. The Archive of the Tomsk Museum of Local Lore. List № 14368/1-136.

9. Dmitrienko, N.M. (2014) Tomskie kuptsy : biograficheskiy slovar' (vtoraya polovina XVIIInachalo $X X v$.) [Tomsk merchants: a biographical dictionary (the second half of the 18th - early 20th centuries)]. Toms: Tomsk State University.

10. Boyko, V.P. (2007) Kupechestvo Zapadnoy Sibiri v kontse XVIII-XIX v.: Ocherki sotsial'noy, otraslevoy, bytovoy $i$ mental'noy istorii [Merchants of Western Siberia at the end of the 18th -19 th centuries: Essays on social, industrial, everyday and mental history]. Tomsk: Tomsk State University og Architecture and Building.

11. Razgon, V.N. (1998) Sibirskoe kupechestvo v XVIII - pervoy polovine XIX v. Regional'nyy aspekt predprinimatel'stva traditsionnogo tipa [Siberian merchants in the 18th - first half of the 19th century. The regional aspect of entrepreneurship of a traditional type]. History Dr. Diss. Barnaul.

12. Rezun, D.Ya. (ed.) (1995) Kratkaya entsiklopediya po istorii kupechestva i kommertsii Sibiri: $v 4 t$. [A Brief Encyclopedia on the History of the Merchants and Commerce of Siberia: In 4 vols]. Vol. 2. Novosibirsk: Nauka.

13. The Tomsk District Executive Committee. (1927) Ekonomicheskiy obzor Tomskogo okruga [Economic Review of Tomsk Okrug]. Tomsk: The Tomsk District Executive Committee.

14. Tomilov, N.A. (2001) Russkie Nizhnego Pritom'ya (konets XIX-pervaya chetvert' XX v.) [The Russians of the Lower Volga Region (the end of the 19th - first quarter of the 20th century)]. Omsk: Omsk State Pedagogical University.

15. The State Archive of Tomsk Region. (n.d.) Vedomosti o fabrikakh i zavodakh v Tomskoy gubernii za $1870 \mathrm{~g}$. [Sheets of factories and plants in the Tomsk province for 1870]. Fund 3. List 18. File 461. pp. 52-53.

16. The State Archive of Tomsk Region. (n.d.) Vedomosti o chastnykh fabrikakh i zavodakh raspolozhennykh v Tomskom okruge za 1871g. [Sheets of private factories and factories located in the Tomsk District for 1871]. Fund 3. List 18. File 497. pp. 29.

17. The State Archive of Tomsk Region. (n.d.) Vedomosti o sostoyanii Ol'ginskogo steklodelatel'nogo zavoda tomskogo kuptsa 1-y gil'dii E.P. Isaeva za 1872 god [Sheets of the state of the Olginsky glass-making plant of the the 1st Guild Tomsk merchant E.P. Isaev for 1872]. Fund 3. List 18. File 532. pp. 97.

18. Zavalishin, I. (1865) Opisanie Zapadnoy Sibiri. Tomskaya guberniya [Description of Western Siberia. Tomsk province]. Vol. 2. Moscow: [s.n.].

19. The State Archive of Tomsk Region. (n.d.) Vedomosti o fabrikakh i zavodakh, nakhodyashchikhsya v vedenii Tomskogo okruga za $1864 \mathrm{~g}$. [Sheets of the factories and plants under the jurisdiction of Tomsk district for 1864]. Fund 3. List 18. File 347.

20. The State Archive of Tomsk Region. (n.d.) Delo o fabrikakh $i$ zavodakh byvshikh $v$ deystvii $v$ techenie 1866 goda [The case of the factories and plants that were in operation during 1866]. Fund 3. List 18. File 353.

21. The State Archive of Tomsk Region. (n.d.) Vedomosti of fabrikakh i zavodakh v Tomskoy gubernii v vedenii Tomskogo okruga Bogorodskoy volosti ot 15 fevralya $1868 \mathrm{~g}$. [Sheets of factories in Tomsk province under the jurisdiction of the Tomsk district of Bogorodskaya Volost on February 15, 1868]. Fund 3. List 18. File 380.

22. The State Archive of Tomsk Region. (n.d.) Vedomosti o fabrikakh i zavodakh sostoyashchikh $v$ vedenii Tomskogo okruga Bogorodskoy volosti 22 oktyabrya 1869 goda [Sheets of factories and plants under the jurisdiction of the Tomsk district of Bogorodskaya Volost on October 22, 1869]. Fund 3. List 18. File 442. 
23. Piletskaya, L.V. (2015) Informativnyy potentsial kollektsiy stekla $v$ gosudarstvennykh muzeyakh Tomskoy oblasti [The informative potential of glass collections in state museums of Tomsk Region]. History Cand. Diss. Tomsk.

24. The State Archive of Tomsk Region. (n.d.) Vedomosti o fabrikakh i zavodakh v Tomskoy gubernii za $1870 \mathrm{~g}$. [Sheets of factories and factories in Tomsk Province for 1870]. Fund 3. List 18. File 461.

25. The State Archive of Tomsk Region. (n.d.) Vedomosti o chastnykh fabrikakh $i$ zavodakh raspolozhennykh v Tomskom okruge za $1871 \mathrm{~g}$. [Sheets of private factories and factories located in the Tomsk district for 1871]. Fund 3. List 18. File 497.

26. The State Archive of Tomsk Region. (n.d.) Obshchey vedomosti o chastnykh fabrikakh, zavodakh $i$ zavedeniyakh $v$ Tomskoy gubernii byvshikh $v$ deystvii $v 1874 \mathrm{~g}$. [General statement on private factories, plants and establishments in Tomsk Province that were in operation in 1874]. Fund 3. List 18. File 586.

27. Bezborodov, M.A. (1965) Tekhnicheskie metody izucheniya drevnikh stekol [Technical methods for the study of ancient glasses]. In: Kolchin, B.A. (ed.) Arkheologiya i estestvennye nauki [Archeology and Natural Sciences]. Moscow: Nauka. pp. 174-177.

28. Kukhta, M., Kazmina, O., Sokolov, A., Arventyeva, N. et al. (2014) The influence of glass and metal properties on the peculiarities of an item of art's shaping in ethnostyle. IOP Conf. Series: Materials Science and Engineering. 66. DOI:10.1088/1757-899X/66/1/012046 